\title{
Effects of anthropogenic activities on chemical contamination within the Grand Canal, China
}

\author{
Xiaolong Wang • Jingyi Han • Ligang Xu • \\ Junfeng Gao $\cdot$ Qi Zhang
}

Received: 12 November 2009 / Accepted: 9 July 2010 / Published online: 31 July 2010

(C) Springer Science+Business Media B.V. 2010

\begin{abstract}
Contamination of nutrients and heavy metals within aquatic system is of great concern due to its potential impact on human and animal health. The Grand Canal of China, the largest artificial river in the world, is of great importance in supplying water resource, transporting cargo, and recreating resident, as well as great historical heritage. This study assessed and examined the impact of human activities on characters of contamination distribution within the section of the Canal in Taihu watershed. Physicochemical parameters of surface water quality were determined monthly from the year 2004 to 2006 at
\end{abstract}

X. Wang · L. Xu · J. Gao · Q. Zhang $(\varangle)$

State Key Laboratory of Lake Science and Environment, Nanjing Institute of Geography and Limnology, Chinese Academy of Sciences, Nanjing 210008, China

e-mail: qzhang@niglas.ac.cn

X. Wang

e-mail: wangxl@niglas.ac.cn

\section{J. Han}

State Key Laboratory of Urban and Regional Ecology, Research Center for Eco-Environmental Sciences, Chinese Academy of Sciences,

Beijing 100085, China

J. Han

Environmental Policy group, Department of Social Sciences, Wageningen University, Hollandseweg 1, 6706 KN Wageningen, The Netherlands
11 sites that were influenced by different anthropogenic activities along the Canal. Moreover, contaminations at surface sediments $(20 \mathrm{~cm})$ at the same locations were also analyzed in September 2006. Results showed that the Canal had been seriously polluted, which was characterized with high spatial variations in contaminations distribution. The sites influenced mainly by industry and urbanization showed higher contents of nutrients and lower levels of dissolve oxygen than other sites. Concentrations of nitrogen at all studied sites exceeded the worst level of surface water quality according to the National Criterion of Surface Water Quality, China, with the average values varying from 2.27 to $10.34 \mathrm{mg} / \mathrm{L}$. Furthermore, the site influenced mainly by industry (i.e., Site 4) presented the highest contents of cadmium (3.453 mg/kg), chromium (196.87 mg/kg), nickel $(87.12 \mathrm{mg} / \mathrm{kg})$, zinc $(381.8 \mathrm{mg} / \mathrm{kg})$, and copper $(357.32 \mathrm{mg} / \mathrm{kg})$. While sites in vicinity to cities had presented relatively higher contents of metals, especially for the site located downstream of Changzhou City (Site 3) had presented the highest contents of mercury $(1.64 \mathrm{mg} / \mathrm{kg})$ and lead $(197.62 \mathrm{mg} / \mathrm{kg})$. Copper at Sites 2 to 6, Nickel at Sites 2 to 9 except for Site 7, chromium, lead, and zinc at Sites 3 to 6 had exceeded New York State Department of Environmental Conservation (NYSDEC) Severe Effect Level (SEL). By multivariate statistical, nutrient variables, companied with $\mathrm{V}$-phen, had contributed the most 
variation of water quality, while nutrient and metals had explained the most part of total variance of contaminations in sediment. This study indicated that the canal had been polluted severely and urgently need to control.

Keywords The Grand Canal • Anthropogenic activities $\cdot$ Water quality $\cdot$ Metals $\cdot$ Sediment

\section{Introduction}

The surface water quality is a matter of serious concern by environmental sciences researchers today. A river or canal is a system comprising both the main course and the tributaries, carrying on one-way flow a significant load of matter in dissolved and particulate phases from both natural and anthropogenic sources (Kunwar et al. 2005; Neal et al. 2006). This matter moves downstream and is subject to intensive chemical and biological transformations (Jarvie et al. 2008; Mdegela et al. 2009). These transformations may be influenced by morphologic and hydrographic factors (Dylan et al. 2005). Seasonal variations in precipitation, surface runoff, groundwater flow and water interception, and abstraction have a strong effect on river discharge and subsequently on the concentration of pollutions in river water (Gibert and Wendy 2003). However, anthropogenic activities in a watershed can also result in pollutant inputs via point and nonpoint sources which may degrade the quality of surface water and impair their use for potable supply, industrial, agricultural, recreation, or other purposes (Simeonova et al. 2003; Kepner et al. 2004). Identification and quantification of these influences should form an important part of managing land and water resources within a particular river catchment (Harris and Heathwaite 2005).

The Grand Canal of China, excavated 1,400 years ago, linking Hanzhou City and Beijing City, is the largest artificial river in the world. It had strongly benefited the development of local society. Furthermore, it had greatly communicated the northern China and southern China for a long history, and because of which, it was endued with great historical heritage worthiness. Nowadays, the Canal also plays a major role in supplying water resource, transporting cargo, and recreating resident, as well as assimilating and carrying off wastewater and agricultural runoff (Zeng et al. 2005). However, in recent years, the Canal was progressively subject to increasing stress from the rapid development of urbanization, industry, agriculture, and aquaculture. Researches in the past 20 years have reported frequently the deterioration of water quality in the Canal, which tended to induce serious ecological and sanitary problems and thus restricted regional sustainable development. Several intensive studies focusing on specific part of the Canal have provided good insight into characters of pollutants input as well as its further influence on aquatic system (Zheng et al. 2001; Chen et al. 2004). However, in order to achieve sustainable management on the water quality at watershed level, it is still badly needed to assess variations of water quality at regional scale and identify influences of different anthropogenic activities on the variation of water quality in the Canal based on long-term and comprehensive investigation (Wang et al. 2007). Identification and quantification of these influences should form an important part of land and water resource management within a particular river system (Massoud et al. 2006).

The goals of this paper were to delineate the characters of the pollution in the Canal and to identify anthropogenic influence on the variation of contamination within the Canal system. Physicochemical parameters of water quality and contaminations of sediment at 11 sites, reflecting different anthropogenic activities effects on the Canal in Taihu watershed, were determined. Multivariate statistical tools were used to evaluate human activities effects on characters of water quality and sediment in the Canal.

\section{Materials and methods}

\section{Study area}

To disentangle the intensive influences of anthropogenic activities on water quality in the Canal, the section of the Canal in Taihu watershed, one of the most developed regions in China, was selected as the study area. The Canal crosses Taihu 
watershed from Yangtze Rive to the eastern border of the Taihu Lake, with its length about $200 \mathrm{~km}$ and over $100 \mathrm{ft}$ wide. It passes through three big cities, viz. Changzhou, Wuxi, and Suzhou, crossing the farmland and rivers along its course with gentle slope and slow velocity. As a result of the rapid development of the local economy and subsequently intensive use of water resources, the Canal has been seriously polluted, which has in return restricted the sustainable development of local economy (Luo et al. 2005).

\section{Sampling site and sample analysis}

Eleven sites influenced by different anthropogenic or natural activities along the Canal were selected to evaluate the chemical contamination within the canal system. Sites 1 and 11 locate in surrounding with farmland; Sites 2, 5, and 8 locate upside of the Changzhou, Wuxi, and Suzhou city, respectively; Sites 3, 6, and 9 locate downside of these three cities; Site 4 locates in an industrial park dominated by chemical plants, leather tanning companies, and synthetic rubber manufacturers; Site 7 is selected at the conjunction of the Canal and Wangyu River, which conveys water from Yangtze Rive to Taihu Lake for the case to abate water pollution of the lake; while Site 10 locates at conjunction the Canal and Taipu River, the main outlet of Taihu Lake.

Surface water sampling (from 0 to $0.5 \mathrm{~m}$ ) was collected at each site monthly during 2004-2006 (Fig. 1). The water samples were immediately preserved in polypropylene sampling bottles at $4^{\circ} \mathrm{C}$ in darkness and analyzed in $48 \mathrm{~h}$. Sediment samples were collected at each site in September 2006 with 0-20 cm layers by using Van Veen grab. Furthermore, sediment samples were also collected from three to five adjacent points for each site and then combined. The parameters of water quality included suspended solids (SS), conductivity (Cond), dissolved oxygen (DO), pH, chemical oxygen demand (COD), biologic oxygen demand (BOD), total nitrogen (TN), ammonium nitrogen $\left(\mathrm{NH}_{3}-\mathrm{N}\right)$, total phosphates (TP), petroleum (Petro), volatile phenolics (V-phen), and dissolved metals $(\mathrm{Hg}, \mathrm{Pb}, \mathrm{Cd}, \mathrm{Cr}$, and $\mathrm{Cu})$. Cond, $\mathrm{pH}$, and DO were determined directly at each sampling site. Cond was measured by YSI meter Model 33, pH was measured by pH meter Beckman Model F8 253, and DO was measured by YSI oxygen meter Model 57,

Fig. 1 Study area and sampling sites within the Grand Canal

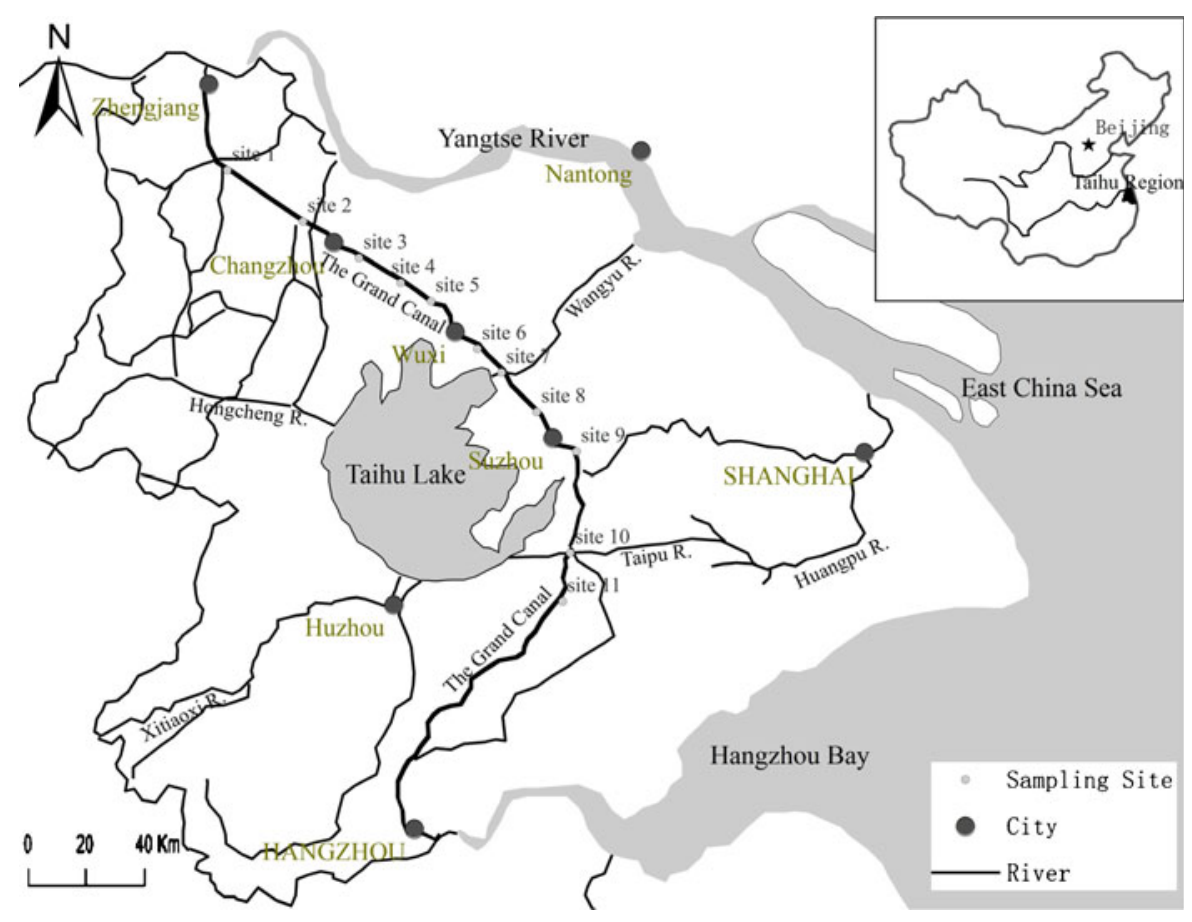


respectively. $\mathrm{SS}, \mathrm{COD}, \mathrm{BOD}, \mathrm{TN}, \mathrm{NH}_{3}-\mathrm{N}$, and TP were determined using standard methods in lab (Chen and Zhao 2004). Petro was measured using Infrared Spectrophotometry method, and $\mathrm{V}$-phen was measured using Flow Injectionspectrophotometric method (Chen and Zhao 2004; Liu 2005). Atomic absorption spectrophotometry was used to determine the concentration of heavy metal within surface sediment according to standard procedures (American Public Health Association 1998). Metal standard solutions (purchased from Sigma-Aldrich, Milwaukee, WI) of $\mathrm{Hg}, \mathrm{Pb}, \mathrm{Cd}, \mathrm{Cr}$, and $\mathrm{Cu}$ were prepared for instrument calibration. All water samples and standards were analyzed using a GBC Atomic Absorption Spectrometer (Arlington Heights, IL) equipped with a flame atomizer. An air/acetylene flame was used for the analysis of $\mathrm{Hg}(520.0 \mathrm{~nm}), \mathrm{Pb}$ $(283.3 \mathrm{~nm}), \mathrm{Cd}(228.8 \mathrm{~nm})$, and $\mathrm{Cu}(324.7 \mathrm{~nm})$ while a nitrous oxide flame was used for all $\mathrm{Cr}$ $(357.9 \mathrm{~nm})$ analyses. Moreover, total organic carbon (TOC), $\mathrm{TN}, \mathrm{NH}_{3}-\mathrm{N}$, and $\mathrm{TP}$ in sediments were also determined using standard methods (Jin 1998).

\section{Data preparation and analysis}

Average values and standard deviation (SD) of water quality and metals in sediment at each site, based on pooled samples in the study period, were determined. Principal component analysis (PCA) and cluster analysis (CA) were employed to identify the characters of the contaminations and sampling stations based on datasets of variables of water quality and metals in sediment, respectively. Non-normality of the data was treated by taking a logarithm or square root, whenever appropriate (Ludwig and Reynolds 1988). PCA was useful for considering several related random environmental variables simultaneously, and so identifying a new, small set of uncorrelated variables that accounted for a large proportion of the total variance in the original variables (Reyment and Joreskog 1993; Lau and Lane 2002; Maria and Graca 2006). Any factor with an eigenvalue greater than unity (eigenvalue $>1$ ) was selected as significant. CA has been proven useful in solving classification problems where the object is to sort cases or variables into groups, such that the de- gree of association is strong between members of the same cluster and weak between members of different clusters (Maria and Graca 2006). To evaluate influence of anthropogenic activities on water quality at studied sites, multivariate cluster analysis was performed using the square of the mean Euclidian distance matrix and the correlation matrix. All statistic analyses were conducted using statistical software package: SPSS 13.0 and significance was determined at the $95 \%$ confidence level.

\section{Results}

Concentrations of water quality parameters

\section{Physical parameters}

The average values and SD of 12 physicochemical parameters of water quality at the 11 sites were listed in Table 1 . The sites influenced by urbanization (Sites 3, 4, 5, 6, 8, and 9) presented significantly higher Cond values than those influenced by agricultural production (Sites 1 and 11) or Taihu Lake outlet (Site 10). This could ascribe to the discharge of industrial and municipal sewage, which releases large amounts alkaline ions into riverine system, since conductivity depends mainly on ions amount in water body (Bernard et al. 2004). Low DO contents were found at Site $3(2.06 \mathrm{mg} / \mathrm{L})$, Site $4(2.33 \mathrm{mg} / \mathrm{L})$, Site $5(2.68 \mathrm{mg} / \mathrm{L})$, and Site $6(2.47 \mathrm{mg} / \mathrm{L})$. This suggested that discharge of industry and municipal wastewater had induced serious organic pollution in the Canal, since DO decreasing was mainly caused by decomposition of organic compound (Donohue et al. 2006). Moreover, extremely low DO content usually indicated deterioration of aquatic system that extinguished fish living (Cai et al. 1997; Zheng et al. 2001). Contrarily, higher DO contents were determined at Sites 1, 2, 10, and 11, ranging from 6.74 to $7.78 \mathrm{mg} / \mathrm{L}$. Average SS values of all sites ranged from 34.22 to $116.21 \mathrm{mg} / \mathrm{L}$. Site 4 showed the highest level of SS, followed by Site $3(98.94 \mathrm{mg} / \mathrm{L})$, Site $6(85.65$ $\mathrm{mg} / \mathrm{L})$, and Site $9(80.57 \mathrm{mg} / \mathrm{L})$, which were located on downside of cities; the lowest content of SS (34.22 mg/L) was determined at Site 10. 
Table 1 Mean values and standard difference (SD) of data of physical and chemical properties of the Grand Canal water at sampling locations during 2004-2006

\begin{tabular}{|c|c|c|c|c|c|c|c|c|c|c|c|c|}
\hline Site & & $\mathrm{pH}$ & $\begin{array}{l}\text { Cond } \\
\mu \mathrm{S} / \mathrm{cm}\end{array}$ & $\begin{array}{l}\mathrm{DO} \\
\mathrm{mg} / \mathrm{L}\end{array}$ & $\begin{array}{l}\mathrm{SS} \\
\mathrm{mg} / \mathrm{L}\end{array}$ & $\begin{array}{l}\mathrm{COD} \\
\mathrm{mg} / \mathrm{L}\end{array}$ & $\begin{array}{l}\mathrm{BOD} \\
\mathrm{mg} / \mathrm{L}\end{array}$ & $\begin{array}{l}\mathrm{TN} \\
\mathrm{mg} / \mathrm{L}\end{array}$ & $\begin{array}{l}\mathrm{NH}_{4}-\mathrm{N} \\
\mathrm{mg} / \mathrm{L}\end{array}$ & $\begin{array}{l}\mathrm{TP} \\
\mathrm{mg} / \mathrm{L}\end{array}$ & $\begin{array}{l}\text { Pretro } \\
\mathrm{mg} / \mathrm{L}\end{array}$ & $\begin{array}{l}\text { V-phen } \\
\text { mg/L } \\
\end{array}$ \\
\hline \multirow[t]{3}{*}{1} & $\mathrm{~N}$ & 34 & 34 & 34 & 34 & 34 & 34 & 34 & 34 & 34 & 34 & 34 \\
\hline & Mean & 7.44 & 35.61 & 7.14 & 55.38 & 4.58 & 1.89 & 3.98 & 1.83 & 0.180 & 0.043 & 0.003 \\
\hline & SD & 0.18 & 9.98 & 1.53 & 30.22 & 0.89 & 0.75 & 1.92 & 1.59 & 0.125 & 0.031 & 0.002 \\
\hline \multirow[t]{3}{*}{2} & $\mathrm{~N}$ & 36 & 36 & 36 & 36 & 36 & 36 & 36 & 36 & 36 & 36 & 36 \\
\hline & Mean & 7.41 & 37.41 & 6.74 & 42.32 & 4.87 & 1.98 & 4.17 & 1.59 & 0.212 & 0.039 & 0.004 \\
\hline & SD & 0.17 & 9.89 & 1.03 & 15.99 & 1.25 & 1.05 & 1.69 & 0.87 & 0.079 & 0.024 & 0.003 \\
\hline \multirow[t]{3}{*}{3} & $\mathrm{~N}$ & 36 & 36 & 36 & 36 & 36 & 36 & 36 & 36 & 36 & 36 & 36 \\
\hline & Mean & 7.56 & 220.14 & 7.06 & 98.94 & 4.69 & 4.09 & 3.02 & 1.80 & 0.227 & 0.111 & 0.006 \\
\hline & SD & 0.21 & 120.46 & 1.67 & 79.93 & 1.44 & 1.63 & 1.31 & 0.53 & 0.083 & 0.178 & 0.004 \\
\hline \multirow[t]{3}{*}{4} & $\mathrm{~N}$ & 36 & 36 & 36 & 36 & 36 & 36 & 36 & 36 & 36 & 36 & 36 \\
\hline & Mean & 7.46 & 316.67 & 2.06 & 116.21 & 7.74 & 6.20 & 5.12 & 2.55 & 0.213 & 0.449 & 0.034 \\
\hline & SD & 0.30 & 210.42 & 1.58 & 44.15 & 2.77 & 3.36 & 1.77 & 1.55 & 0.108 & 0.216 & 0.009 \\
\hline \multirow[t]{3}{*}{5} & $\mathrm{~N}$ & 36 & 36 & 36 & 36 & 36 & 36 & 36 & 36 & 36 & 36 & 36 \\
\hline & Mean & 7.42 & 54.58 & 2.33 & 70.83 & 5.90 & 5.41 & 6.76 & 3.94 & 0.264 & 0.125 & 0.010 \\
\hline & SD & 0.38 & 18.85 & 1.50 & 41.35 & 2.29 & 5.28 & 2.72 & 2.04 & 0.099 & 0.108 & 0.010 \\
\hline \multirow[t]{3}{*}{6} & $\mathrm{~N}$ & 36 & 36 & 36 & 36 & 36 & 36 & 36 & 36 & 36 & 36 & 36 \\
\hline & Mean & 7.48 & 61.46 & 2.68 & 85.65 & 7.58 & 7.56 & 9.77 & 6.48 & 0.257 & 0.172 & 0.011 \\
\hline & SD & 0.30 & 19.46 & 1.24 & 22.13 & 2.27 & 4.87 & 3.60 & 3.08 & 0.088 & 0.098 & 0.005 \\
\hline \multirow[t]{3}{*}{7} & $\mathrm{~N}$ & 36 & 36 & 36 & 36 & 36 & 36 & 36 & 36 & 36 & 36 & 36 \\
\hline & Mean & 7.35 & 74.29 & 4.47 & 65.57 & 9.33 & 8.01 & 10.34 & 6.61 & 0.353 & 0.205 & 0.006 \\
\hline & SD & 0.23 & 24.56 & 1.02 & 26.19 & 2.36 & 4.07 & 3.52 & 2.49 & 0.160 & 0.114 & 0.012 \\
\hline \multirow[t]{3}{*}{8} & $\mathrm{~N}$ & 36 & 36 & 36 & 36 & 36 & 36 & 36 & 36 & 36 & 36 & 36 \\
\hline & Mean & 7.34 & 367.53 & 4.02 & 58.26 & 8.74 & 5.82 & 8.85 & 5.19 & 0.215 & 0.233 & 0.008 \\
\hline & SD & 0.25 & 220.37 & 1.26 & 30.50 & 2.59 & 3.35 & 2.46 & 2.47 & 0.145 & 0.110 & 0.005 \\
\hline \multirow[t]{3}{*}{9} & $\mathrm{~N}$ & 36 & 36 & 36 & 36 & 36 & 36 & 36 & 36 & 36 & 36 & 36 \\
\hline & Mean & 7.40 & 345.83 & 4.61 & 80.57 & 7.16 & 4.13 & 7.62 & 5.65 & 0.226 & 0.172 & 0.007 \\
\hline & SD & 0.22 & 261.32 & 1.71 & 27.79 & 1.72 & 1.59 & 2.21 & 2.07 & 0.083 & 0.143 & 0.004 \\
\hline \multirow[t]{3}{*}{10} & $\mathrm{~N}$ & 33 & 33 & 33 & 33 & 33 & 33 & 33 & 33 & 33 & 33 & 33 \\
\hline & Mean & 7.35 & 47.11 & 7.78 & 34.22 & 4.49 & 3.02 & 2.27 & 1.54 & 0.101 & 0.033 & 0.004 \\
\hline & SD & 0.24 & 15.16 & 1.41 & 14.33 & 1.07 & 1.32 & 0.78 & 0.43 & 0.045 & 0.021 & 0.001 \\
\hline \multirow[t]{3}{*}{11} & $\mathrm{~N}$ & 36 & 36 & 36 & 36 & 36 & 36 & 36 & 36 & 36 & 36 & 36 \\
\hline & Mean & 7.37 & 66.82 & 6.98 & 54.25 & 6.77 & 3.86 & 4.54 & 3.65 & 0.105 & 0.062 & 0.003 \\
\hline & SD & 0.28 & 24.13 & 1.60 & 17.17 & 1.33 & 2.22 & 3.08 & 2.63 & 0.266 & 0.024 & 0.004 \\
\hline
\end{tabular}

\section{Chemical parameters}

Average values of $\mathrm{pH}$ at the 11 sites showed less variation, ranging from 7.34 to 7.56 . The highest value of COD was founded at Site $7(9.33 \mathrm{mg} / \mathrm{L})$; the sites influenced by urbanization and industry (Sites 4, 5, 6, 8, and 9) presented relatively high contents of COD, ranging from 6.90 to 8.74 $\mathrm{mg} / \mathrm{L}$; while Site 10 showed the lowest contents of COD (4.49 mg/L). Similar trend was found with that of BOD. Significant diversities in average values of TN (2.27-10.34 mg/L) and $\mathrm{NH}_{3}-$ $\mathrm{N}$ (1.54-6.61 mg/L) were found among studied sites. Site 7 showed the highest contents of TN and $\mathrm{NH}_{3}-\mathrm{N}$, while Site 10 showed the lowest ones. The highest value of TP was determined at Site $10(0.101 \mathrm{mg} / \mathrm{L})$, while the lowest at Site 7 $(0.353 \mathrm{mg} / \mathrm{L})$. Sites nearby the Wuxi City showed higher TP concentrations than other sites except for Site 7; while sites surrounded by farmland (Sites 1 and 11) presented relatively lower contents of TP.

Sites 1, 2, 10, and 11 showed relatively lower contents of Petro than that of other sites with the values ranging from 0.033 to $0.043 \mathrm{mg} / \mathrm{L}$. Less significant differences of $\mathrm{V}$-phen concentrations were found at all the studied sites except for Site 4 . The highest concentrations of Pretro $(0.449 \mathrm{mg} / \mathrm{L})$ and V-phen $(0.058 \mathrm{mg} / \mathrm{L})$ were determined at Site 4. Several studies had revealed that Petroleum in 
Fig. 2 Contents of cadmium, chromium, nickel, mercury, lead, zinc, and copper of sediments within 11 sampling sites in the Grand Canal along with LEL and SEL of NYSDEC
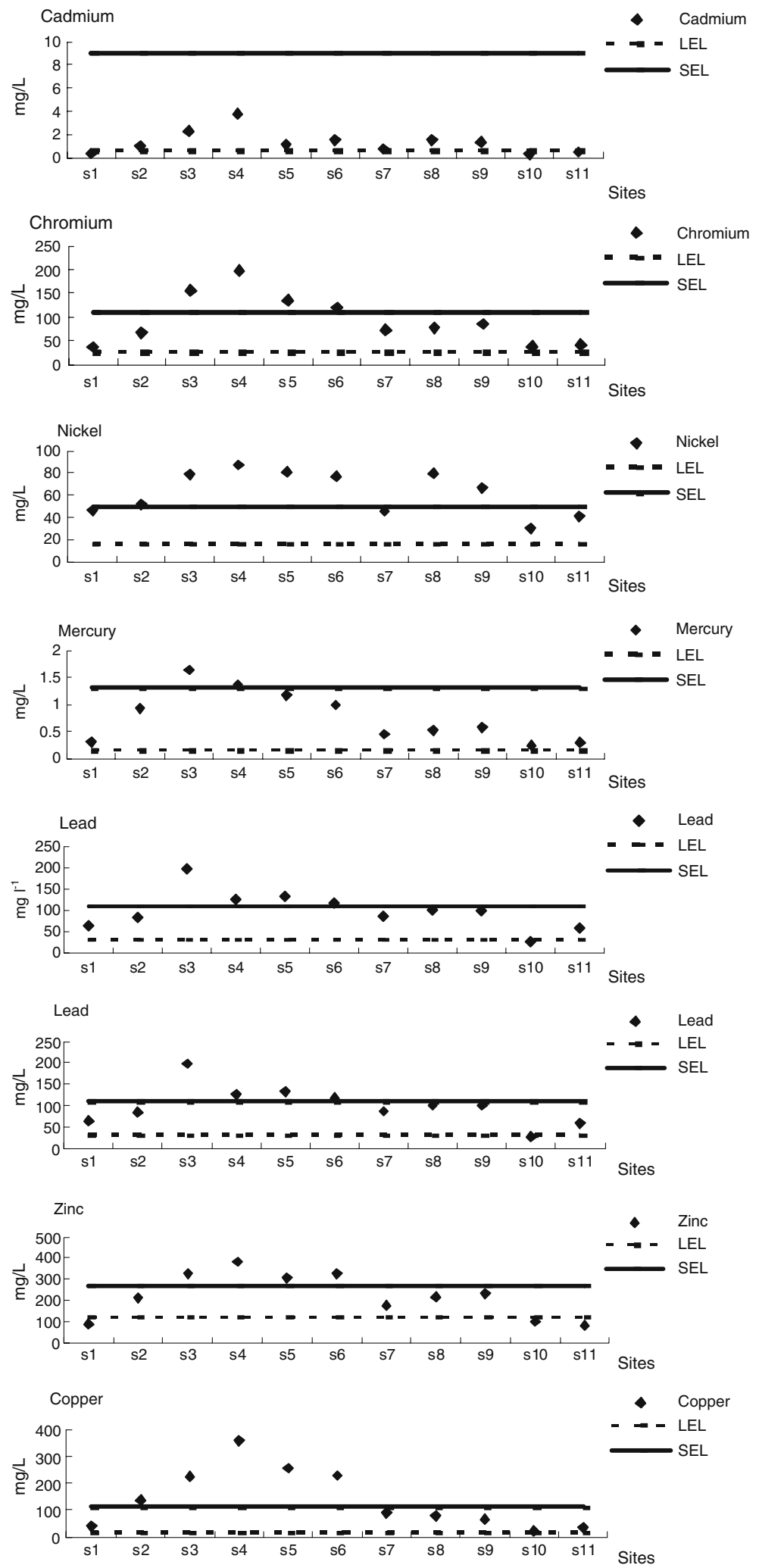
rivers of Taihu watershed mainly came from ships (Cai et al. 1997). However, highest concentration of Pretro was found at Site 4 with lower values at other sites suggested that Petroleum pollution in the Canal was mostly related to industry. Highest concentration of V-phen was determined at Site 4 and may also be ascribed to discharge of wastewater from the industry park, considering that $\mathrm{V}$-phen mainly came from sewage of organicchemistry industries (Luo et al. 2005).

Concentrations of metals in sediments

Figure 2 shows the concentrations of metals (cadmium, chromium, nickel, mercury, lead, zinc and copper) in sediments at the studied sites (Fig. 2). In order to assess metal concentrations in sediment from a regulatory perspective, the New York State Department of Environmental Conservation (NYSDEC 1999) guidelines will be referred. Two levels of risk for potential impacts to biota have been established in NYSDEC, based on total metal concentration in sediment: (1) lowest effect level (LEL); and (2) severe effect level (SEL). If the LEL is exceeded, the metal may moderately impact biota health. If the SEL is exceeded, the metal may severely impact biota health.

The highest concentrations of cadmium, chromium, nickel, zinc and copper were measured at Site 4, whereas the highest contents of mer- cury and lead were determined at Site 3. The relatively higher concentrations of metals were determined at Sites 5 and 6, while Sites 1, 10, and 11 presented lower concentrations of cadmium, chromium, mercury, zinc, and copper than other sites. Cadmium concentrations varied in a wide range from 0.281 to $3.753 \mathrm{mg} / \mathrm{kg}$. Samples from Sites 3 to 9 exceed the NYSDEC LEL, while no sample exceeded the NYSDEC SEL. Chromium concentrations ranged from 36.7 to $196.87 \mathrm{mg} / \mathrm{kg}$. Samples from all sites exceeded the NYSDEC LEL, among which the concentrations of chromium at Sites 3 to 6 exceeded the NYSDEC SEL, with the values 155.63, 169.87, 134.73, and $120.68 \mathrm{mg} / \mathrm{kg}$, respectively. Average concentrations of Copper at all sites exceeded NYSDEC LEL, with the range from 22.33 to $357.32 \mathrm{mg} / \mathrm{kg}$. Samples in the locations influenced by industry and urbanization (Sites 2 to 6) exceeded the NYSDEC SEL. Average contents of nickel varied from 30.21 to $120.68 \mathrm{mg} / \mathrm{kg}$, presenting less spatial variations among studied sites than other metals. Concentrations of nickel at all sites exceeded the NYSDEC LEL, while sites influenced by industry and urbanization (Sites 2 to 6, 8, and 9) exceeded the NYSDEC SEL. The average contents of Mercury ranged from 0.29 to $1.64 \mathrm{mg} / \mathrm{kg}$. Although no sample exceeded the NYSDEC SEL, all samples exceeded the NYSDEC LEL. As far as lead and zinc were concerned, their average contents were varied in the

Table 2 Rotated component matrix of PCA on date sets during Wet-season and Dry-season, respectively

\begin{tabular}{|c|c|c|c|c|c|c|}
\hline \multirow[t]{2}{*}{ Variables } & \multicolumn{3}{|c|}{ Water samples } & \multirow[t]{2}{*}{ Variables } & \multicolumn{2}{|c|}{ Sediments } \\
\hline & Factor 1 & Factor 2 & Factor 3 & & Factor 1 & Factor 2 \\
\hline$\overline{\mathrm{pH}}$ & -0.301 & 0.869 & -0.187 & TOC & 0.805 & 0.304 \\
\hline $\mathrm{DO}$ & -0.932 & 0.157 & -0.049 & $\mathrm{TN}$ & 0.793 & 0.209 \\
\hline Cond & 0.013 & 0.845 & 0.246 & $\mathrm{NH}_{4}-\mathrm{N}$ & 0.834 & 0.028 \\
\hline SS & -0.047 & 0.891 & 0.257 & $\mathrm{TP}$ & 0.913 & 0.247 \\
\hline COD & 0.825 & -0.277 & 0.333 & Cadmium & 0.875 & -0.057 \\
\hline BOD & 0.962 & 0.027 & -0.076 & Chromium & 0.920 & -0.083 \\
\hline $\mathrm{TN}$ & 0.772 & -0.284 & 0.278 & Nickel & 0.832 & 0.385 \\
\hline $\mathrm{NH}_{4}-\mathrm{N}$ & 0.856 & -0.034 & 0.247 & Mercury & 0.857 & 0.421 \\
\hline $\mathrm{TP}$ & 0.894 & -0.173 & 0.229 & Lead & 0.274 & 0.813 \\
\hline Pretro & 0.407 & 0.488 & 0.733 & Zinc & 0.894 & 0.234 \\
\hline V-phen & 0.832 & 0.210 & 0.136 & Copper & 0.324 & 0.759 \\
\hline Eigen-values & 4.9 & 2.5 & 1.4 & & 5.2 & 1.8 \\
\hline Total variance (\%) & 46.1 & 24.3 & 13.5 & & 53.4 & 19.3 \\
\hline Cumulative (\%) & 46.1 & 70.4 & 83.9 & & 53.4 & 72.7 \\
\hline
\end{tabular}


range from 26.37 to $197.62 \mathrm{mg} / \mathrm{kg}$ and from 79.63 to $381.8 \mathrm{mg} / \mathrm{kg}$, respectively. Most sites showed the values of zinc above the NYSDEC LEL with exception of Sites 1, 10, and 11; whereas average values of lead at all sites exceeded the LEL only except for Site 10. Similar to that of chromium, contents of lead and zinc exceeded the NYSDEC SEL at Sites 3 to 6.
Classification on the anthropogenic influences on contamination within the Grand Canal

PCA was performed to identify the characters of contaminations at all studied sites, based on data sets of variables of both water quality and contaminations in sediment. The significant factors (i.e., eigenvalue $>1$ ) loading matrix of PCA
Fig. 3 Plot of factor loadings for each variable of the first two factor axes of a water quality data and $\mathbf{b}$ sediment contamination data (a)
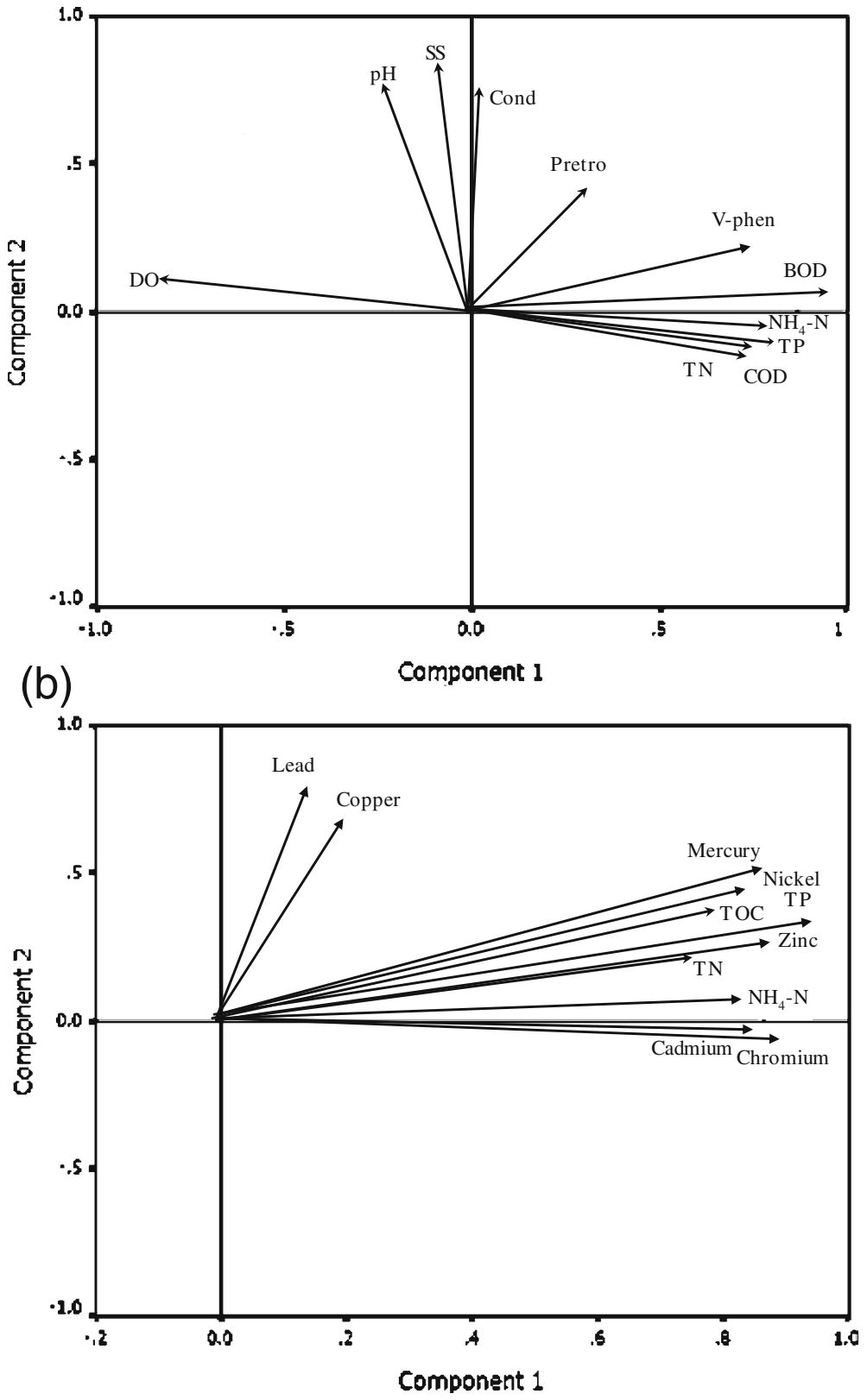
was listed in Table 2 and the planar plot of the variables against their values for axes $\mathrm{X}$ and $\mathrm{Y}$ was presented as Fig. 3. Factor analysis of water quality data set shows that the eigenvalues for three significant factors are 4.9, 2.5. and 1.4, respectively, accounting for $83.9 \%$ of the total variables. The first factor accounted for $46.1 \%$ of the total variance and is positively related to all nutrient variables (COD, BOD, TN, $\mathrm{NH}_{3}-\mathrm{N}$, and TP) and V-phen, and negatively related to DO. Factor 2 explains $24.3 \%$ of the total variance and is significantly related to $\mathrm{pH}, \mathrm{SS}$, and Cond. Factor 3 accounted for $13.5 \%$ of the total variance and is only significantly related to Petro. Only two significant factors (i.e., eigenvalue $>1$ ) were extracted by PCA based on sediment data set (with eigenvalues of 5.2 for Factor 1 and 1.8 for Factor 2), which explained $72.7 \%$ of the total variation. The first factor accounted for $53.4 \%$ of the total variance and captures all nutrient related variables (TOC, $\mathrm{TN}, \mathrm{NH}_{3}-\mathrm{N}$, and $\mathrm{TP}$ ) and most metal variables (lead, chromium, cadmium, nickel, mercury, and zinc), while Factor 2 explained $19.3 \%$ of the total variance and related to lead and copper.

To examine anthropogenic influences on distribution of contamination within the Canal, multivariate CA was applied to classify the studied sites based on datasets of variables of water quality and contaminations in sediment, respectively. Two dendrograms produced by multivariate CA were shown as Fig. 4. There are four major groups obtained by CA, based on the physiochemical variables of water quality. Group 1 is related with sites mostly influenced by agricultural runoff (Sites 1, 2, and 11), whereas Group 2 comprises only Site 10 , representing the dilution by the water from Taihu Lake outlet. Group 3 consists of all the sites influenced by urbanization and industry (Sites 3 to 6, 8, and 9). Site 7 exclusively forms
Fig. 4 Dendrogram of Q-Hierarchical Cluster Analysis for physiochemical variables of water quality data (a) and sediment contamination dataset (b) a)

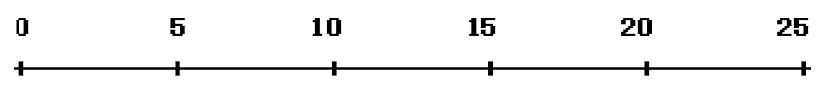

\begin{tabular}{|c|}
\hline Site 2 \\
\hline Site 11 \\
\hline Site 1 \\
\hline Site 10 \\
\hline Site 5 \\
\hline Site 4 \\
\hline Site 6 \\
\hline Site 3 \\
\hline Site 9 \\
\hline Site 8 \\
\hline Site 7 \\
\hline
\end{tabular}

b)

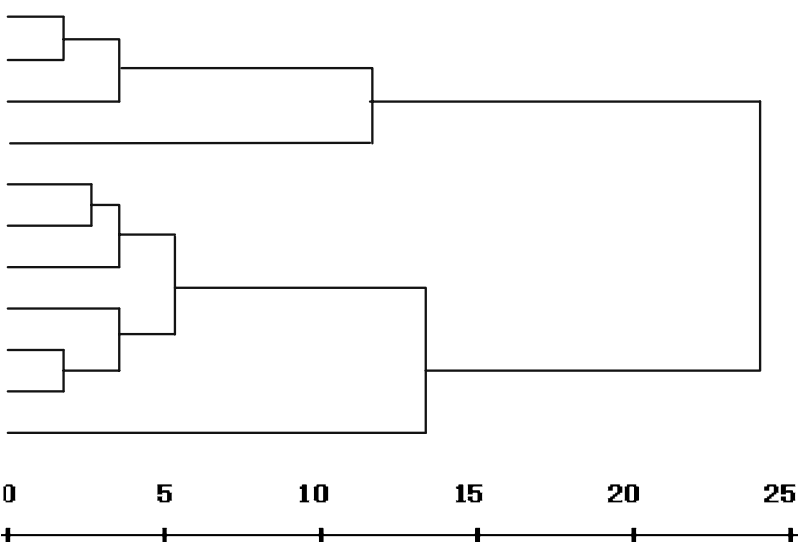

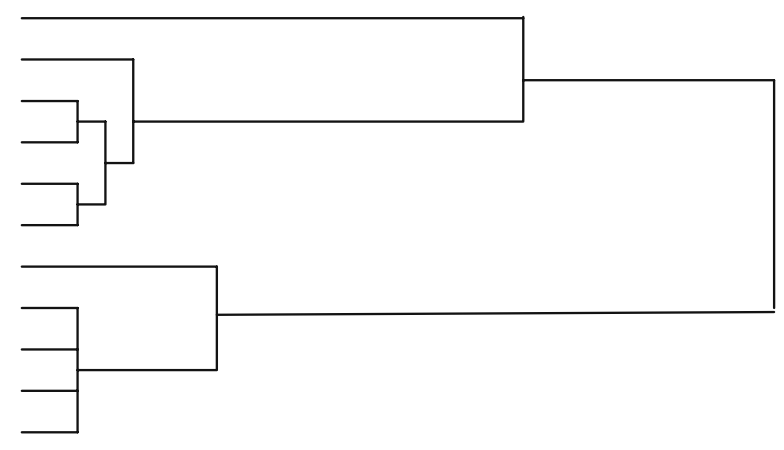


group 4, which represents a compound pollution of agricultural runoff, untreated municipal wastewater, and contaminations from Yangtze Rive. For database of metals in sediment, the 11 studied sites were divided into three groups. Group 1 is formed by Site 4, representing locations polluted by industry characterizing with highest concentrations of metals in surface sediments. Group 2 was presented by locations influenced by urbanization. All sites in the vicinity of cities except for Site 2 were gathered in the assemblage characterized by relatively high contents of metals in surface sediments, which were from the increasing discharge of domestic sewage during urbanization. Considering serious eco-risk of metals accumulation, it suggests significant contaminations on the Canal aquatic ecosystem. Group 3 consisted of the other five sites influenced mainly by agricultural or dilution of Taihu Lake. This group represented slightly metal polluted locations assemblage, in view that less content of metals was determined in the surface sediments at these sites.

\section{Discussions}

COD, TN, and TP are dominating supervised indicators for surface water quality in China. High COD content usually decreases the DO level in surface water body, which undermines health of aquatic ecosystems (Kirchner et al. 2000). Phosphorus and nitrogen in rivers not only induce alga bloom in riverine system but also increase eutrophication risks in lakes and reservoirs (Neal et al. 2005). Since the 1990s, increasing attention and investment have been made by the central and local governments to control the accelerating deterioration of surface water quality in Taihu watershed. All industries and public sectors in the region were obliged to treat their wastewater before discharging it to the natural water body and to use nonphosphorous detergents instead of detergents containing phosphorous (Pan et al. 2005). As a river of such importance, the studied sites of the Canal in this research, which were influenced by industry and urbanization, still presented low DO level and high concentrations of nutrients. Despite that the TN contents at the sites influenced by agricul- tural production were relatively low, the concentrations of nitrogen at all sites exceeded the fifth standard (the worst level of water quality, $\mathrm{TN}>$ $2.0 \mathrm{mg} / \mathrm{L}$ ) of the National Criterion of Surface Water Quality, China. This suggested that nitrogen should be considered in priority for local water pollution abatement. Many studies argued that water quality in rivers varied from upside to downside with a degrading trend due to the hydraulic droving (Haygarth et al. 2005; Jarvie et al. 2008). However, in this study less variation was found in nutrients concentrations between sites located upside and downside of cities respectively (Sites 5, and 6; Sites 8 and 9). Water quality at the sites subjected to industry and urbanization was more degraded than others. This was also approved by the results of $\mathrm{CA}$ in view that all sites influenced by industry and urbanization were clustered into one group. Water quality in the Canal was more related to the surrounding social and economic structure. Of course, the low velocity of current in the Canal was also an important contributor for decelerating the transport and diffuses of nutrients (Zheng et al. 2001; Zhang et al. 2004).

For abating the water pollution and recovering the aquatic system of Taihu Lake, a great project was conducted to lead fresh water from Yangtze Rive to Taihu Lake through the Wangyu River. However, Site 7, located at the conjunction of the Canal and Wangyu River, showed higher values of COD, BOD, TN, $\mathrm{NH}_{3}-\mathrm{N}$, and TP than that in the Taihu Lake. It indicated that more pollutants were input to Taihu Lake after the project (Cao and Zhou 2006). Considering that water quality in Yangtze Rive was better than that of the outlet of Wangyu River near Taihu Lake, the high contents of pollutions at Site 7 must be ascribed to the wastewater discharged from the cities along Wangyu River (Pu et al. 1998; Wang et al. 2007).

Heavy metals are a special group of contaminants with high ecological significance in aquatic systems. They cannot be self-purified by the water body. As a result, heavy metals always accumulate in the bottom sediment of rivers and enter the food chain (Graney and Eriksen 2004; Dalmacija et al. 2006; Geoffrey et al. 2008). The occurrence of heavy metals in the environment results primarily from anthropogenic activities, though the natural processes that may enrich waters with trace 
elements also play a noticeable role (Zoumins et al. 2001; Janel et al. 2006). In the present study, the location influenced mainly by industry (Site 4) presents the highest contents of cadmium, chromium, nickel, zinc, and copper. It suggests that discharge of industry wastewater is playing a dominant role in the accumulation of heavy metal contaminants in the surface sediment in the Canal. The sites in vicinity to the big cities presented relatively high contents of metals. Notably, the site located on the downside of Changzhou City (Site 3) was determined with the highest values of mercury and lead. Mercury usually escapes from electrolytic $\mathrm{Cl}_{2}$ production and Lead is employed as stabilizers and additives in the synthesis rubber and PVC. These manufactures are rapidly developed in the past decades in Changzhou city, which increased the load of mercury and lead to the Canal (Liu et al. 1999; Qu et al. 2001). Sites apart from industry and urbanization presented lower concentrations of metals in surface sediment. This indicated that the agricultural activities contribute less to the metal contamination in the Canal. Generally, runoff from different types of land use is enriched with different kinds of contaminants. For example, runoff from agricultural lands may be enriched with nutrients and sediments. Likewise, runoff from highly developed urban areas is enriched with heavy metals and sulfate (Lawlor and Tipping 2003; Evans et al. 2005). The distinct influences of different anthropologic activities on metal contaminants in the Canal were also distinguished by the CA, which formed three groups that were influenced by industry, urbanization and agricultural production, respectively.

In this study, by using PCA, variables were reduced into three and two key independent factors for datasets of water quality and sediment, respectively. Nutrient variables and V-phen contributed the greatest variance of total variation of water quality, which presented the dominant environmental problems to the Canal. Considering that V-phen mainly came from sewage of organicchemistry industry, high consistency in variations of nutrients and $\mathrm{V}$-phen suggested urbanization and industry played a dominant role in variation of water quality within the Canal, although $\mathrm{CaO}$ et al. (2004) and Wang et al. (2004) argued that runoff from agricultural contributed more than
$60 \%$ nutrients loss in Taihu Region. Only Petro significantly related to factor 3 (counting for $13.5 \%$ of the total variance of water quality), which indicated that shipping is an important pollutant resource to the Canal, in view that Petroleum in rivers of Taihu watershed mainly leaked from watercrafts (Cai et al. 1997). Nutrient and metals contributed to the components that explained $53.4 \%$ of the total variance in sediment. The high assembling of nutrient variables and metals in sediment suggested the strong similarity in the sources of nutrient and metals in the Canal.

\section{Conclusions}

The contamination of nutrients and heavy metals within aquatic system is of great concern due to their potential impacts on ecosystems and human health. In this study, the Canal was characterized with high spatial variations in water quality and the heavy metals in surface sediment. Sites influenced by industry and urbanization showed higher contents of nutrients and lower DO levels in water body. Moreover, more efforts should be made on contamination abatement along the Wangyu River in view of its great contribution to pollutants load to the Canal. Nitrogen was the principal polluted parameter within the Canal, as its values at all studied sites exceeded the worst level of water quality of the National Criterion of Surface Water Quality, China. The site influenced mainly by industry presented the highest contents of cadmium, chromium, nickel, zinc and copper, and sites in vicinity to cities also presented relative high contents of metals, whereas sites influenced by nonpoint sources presented fewer contents of metals. Compared with NYSDEC guidelines, contents of chromium, nickel, copper, lead and zinc within sediment exceeded the NYSDEC SEL at sites influenced by industry and urbanization (Sites 3 to 6). By multivariate statistical, the nutrients, companied with $\mathrm{V}$-phen, contributed the most variation of water quality. They were the dominant environmental problems in water body. The nutrients and metals explained the most part of total variance of contaminations in sediment. They were also highly consistent in variations, which indicated strong similarity in the sources of 
nutrient and metals in the Canal. Anthropogenic activities contributed the most loads of contaminations and influenced their spatial distribution significantly in the Canal. In conclusion, the Canal had been severely contaminated with nutrients and heavy metals. Regular monitoring on water quality in the Canal is in urgent need. Future works should focus on the potential ecological and toxicity hazard of the contamination in the Canal.

Acknowledgements This work was supported by the Foundation of National Key Basic Research, China (2008CB418104) and the National Scientific Foundation of China (Grant 40801197).

\section{References}

American Public Health Association (1998). Metals by flame atomic absorption spectrometry. In L. S. Clesceri, A. E. Greenberg, \& A. D. Eaton (Eds.), Standard methods for the examination of water and wastewater (20th ed., pp. 3-1303-22). Washington, DC: American Public Health Association.

Bernard, P., Antoine, L., \& Bernard, L. (2004). Principal component analysis: An appropriate tool for water quality evaluation and management-application to a tropical lake system. Ecological Modelling, 178, 295-311.

Cai, Q. M., Gao, X. Y., Chen, Y. W., Ma, S. W., \& Dokulil, M. (1997). Dynamic variations of water quality in Taihu Lake and multivariate analysis of its influential factors. Journal of Chinese Geography, 7, 72-82.

Cao, C., Zhu, J. G., Zhu, J. Y., Cao, X., Dou, Y. J., \& Hosen, Y. (2004). Nitrogen export from an agriculture watershed in the Taihu Lake area. Environmental Geochemistry and Health, China, 26, 199-207.

Cao, X. H., \& Zhou, E. (2006). Influence of water diversion of Wangyu River on water environment of west Changshu City. Water Resource Protection, China, 22, 48-50.

Chen, L., \& Zhao, J. F. (2004). Environmental monitor. Beijing: Chemical Industry Press.

Chen, Y. X., Liu, H., Zhu, G. W., \& Chen, H. (2004). Pollution characteristics of the recent sediments in the Hangzhou section of the Grand Canal, China. Journal of Environmental Sciences, 16, 34-39.

Dalmacija, B., Prica, M., Ivancev-Tumbas, I., Van der Kooij, Roncevic, S., Krcmar, T., et al. (2006). Pollution of the Begej Canal sediment-metals, radioactivity and toxicity assessment. Environmental International, 32, 606-615.

Donohue, I., Martin, L., Garrigle, M., Paul, M. (2006). Linking catchment characteristics and water chemistry with the ecological status of Irish rivers. Water Research, 40, 91-98.
Dylan, S., Richard, W., Sheibley, R. A., Dahlgren, M. A., Joshua, J., \& Kenneth, W. T. (2005). Land use and land cover influence on water quality in the last free-flowing river draining the western Sierra Nevada, California. Journal of Hydrology, 313, 234-247.

Evans, C. D., Monteith, D. T., \& Cooper, D. M. (2005). Long-term increases in surface water dissolved organic carbon: Observations, possible causes and environmental impacts. Environmental Pollution, 137, 55-71.

Geoffrey, J. P., Ranjeet, K. T., Hua, Z., David, Y., Brent, M. P., \& Luying, X. (2008). Mobility and recalcitrance of organo-chromium (III) complexes. Chemosphere, 70, 2054-2059.

Gibert, C. S., \& Wendy, A. T. (2003). Watershed scale assessment of nitrogen and phosphorus loadings in the Indian River Lagoon basin, Florida. Environmental Management, 67, 363-372.

Graney, J. R. \& Eriksen, T. M. (2004). Metals in pond sediments as archives of anthropogenic activities: A study in response to health concerns. Applied Geochemistry, 19, 1177-1188.

Harris, G. P., \& Heathwaite, A. L. (2005). Inadmissible evidence: Knowledge and prediction in land and riverscapes. Journal of Hydrology, 304, 3-19.

Haygarth, P. M., Wood, F., Heathwaite, A. L., \& Butler, P. (2005). Phosphorus dynamics observed through increasing scales in a nested headwater-to-river channel study. Science of the Total Environment, 344, 83-106.

Janel, E., Owens, E. D., \& Niemeyer, D. (2006). Analysis of chemical contamination within a canal in a Mexican border colonia. Environmental Pollution, 140, 506515.

Jarvie, H. P., Haygarth, P. M., Neal, C., Butler, P., \& Smith, B. (2008). Stream water chemistry and quality along an upland-lowland rural land-use continuum, south west England. Journal of Hydrology, 350, 215-231.

Jin, X. C. (1998). Criterion of eutrophiction survey on lakes. Beijing: Environmental Science Press.

Kepner, G. W., Semmens, J. D., Bassett, D. S., Mouat, A. D., \& Goodrich, C. D. (2004). Scenario analysis for the San Pedro River, analysing hydrological consequences of a future environment. Environment Monitor and Assessment, 94, 115-127.

Kirchner, J. W., Feng, X., \& Neal, C. (2000). Fractal stream chemistry and its implications for contaminant transport in catchments. Nature, 403, 524-527.

Kunwar, P. S., Amrita, M., \& Sarita, S. (2005). Water quality assessment and apportionment of pollution sources of Gomti River (India) using multivariate statistical techniques-a case study. Analytical Chimical Acta, 538, 355-374.

Lau, S. S. S., \& Lane, S. N. (2002). Biological and chemical factors influencing shallow lake eutrophication: A long-term study. Science of the Total Environment, 228, 167-181.

Lawlor, A. J., \& Tipping, E. (2003). Metals in bulk deposition and surface waters at two upland locations in Northern England. Environmental Pollution, 121, 153-168. 
Liu, L. (2005). Research of measure methods of petroleumlike matters in industrial waste water. Metallurgical Power, China, 111, 60-63.

Liu, W., Wang, Z., Wen, X., \& Tang, H. (1999). The application of preliminary sediment quality criteria to metal contamination in the Le An River. Environmental Pollution, 105, 355-366.

Ludwig, J. A., \& Reynolds, J. F. (1988). Statistical ecology. New York: Wiley.

Luo, J., Pang, Y., \& Yang, S. (2005). Study on flux of pollutants discharged into Taihu Lake through main inflow river channels. Journal of Hohai University, 33, $131-135$.

Maria, J. B., \& Graca, C. (2006). Identification of similar environmental areas in Tagus estuary by using multivariate analysis. Ecological Indictor, 6, 508-515.

Massoud, M., El-Fadel, M., Scrimshaw, M. D., \& Lester, J. N. (2006). Factors influencing development of management strategies for the Abou Ali River in North Lebanon I: Spatial variation and land use. Science of the Total Environment, 362, 15-30.

Mdegela, R. H., Braathen, M., Rereka, A. E. P., Mosha, D., Sandvik, M., \& Skaare, J. U. (2009). Heavy metals and organochlorine residues in water, sediments, and fish in aquatic ecosystems in Urban and Peri-Urban areas in Tanzania. Water, Air, and Soil Pollution, 203(1-4), 369-379.

Neal, C., House, W. A., Jarvie, H. P., Neal, M., Hill, L., \& Wickham, H. (2005). Phosphorus concentrations in the River Dun, the Kennet and Avon Canal and the River Kennet, southern England. Science of the Total Environment, 344, 107-128.

Neal, C., House, W. A., Helen, P., Margaret, N., Linda, H., \& Heather, W. (2006). The water quality of the River Dun and the Kennet and Avon Canal. Journal of Hydrology, 330, 155-170.

NYSDEC (New York State Department of Environmental Conservation) (1999). Technical guidance for screening contaminated sediments. Albany: Division of Fish, Wildlife and Marine Resource.

Pan, S. B., Cao, L. P., \& Zhang, J. L. (2005). Water quality management in China: Situation, problems and challenges. Water Resource Protection, China, 21, 59-62.

Pu, P. M., Hu, W. P., Yan, J. S., Wang, G. X., \& Hu, C. G. (1998). A physico-ecological engineering experiment for water treatment in a hypertrophic lake in China. Ecollgical Engineering, 10, 179-190.

Qu, W. C., Mike, D., \& Wang, S. M. (2001). Multivariate analysis of heavy metal and nutrient concentrations in sediments of Taihu Lake, China. Hydrobiologia, 450, 83-89.

Reyment, R., Joreskog, K. G. (1993). Applied factor analysis in the natural sciences. Cambridge: Cambridge University Press.

Simeonova, V., Stratisb, J. A., Samarac, C., Zachariadisb, G., Voutsac, D., \& Anthemidis, A. (2003). Assessment of the surface water quality in Northern Greece. Water Research, 37, 4119-4124.

Wang, X. L., Lu, Y. L., Han, J. Y., He, G. Z., \& Wang, T. Y. (2004). Identification of anthropogenic influences on water quality of rivers in Taihu watershed. Journal of Environmental Science, 9, 475-481.

Wang, X. L., Lu, Y. L., He, G. Z., Wang, T. Y., \& Han, J. Y. (2007). Multivariate analysis of interactions between phytoplankton biomass and environmental variables in Taihu Lake, China. Environmental Monitor and Assessment, 133, 243-253.

Zeng, A. B.,Wang, C. H., \& Ruan, J. N. (2005). The water quality analysis for Beijin-Hangzhou Grand Canal (Hangzhou Section) and countermeasures for pollution. Journal of Shenyang Agricultural University, 36, 631-633.

Zhang, L., Fan, C. X., Chi, Q. Q., Wang, J. J., \& Qin, B. Q. (2004). Phosphorus species distribution of sediments in Lake Taihu and its main inflow rivers. Geochemistry, China, 33, 423-432.

Zheng, Y., Wang, X. J., \& Liu, X. B. (2001). Analysis on water quality of rivers around Tai Lake and estimation of total pollutant load into Tai Lake. China Lake Science, 17, 40-44.

Zoumins, T., Schmidt, A., Grigorova, L., \& Calmano, W. (2001). Contaminant in sediments: Remobilization and demobilization. Science of the Total Environment, 266, 195-202. 